\title{
Resistance status of Anopheles gambiae (s.l.) to four commonly used insecticides for malaria vector control in South-East Nigeria
}

\author{
Okechukwu Chukwuekezie ${ }^{1}$, Emmanuel Nwosu', Udoka Nwangwu' ${ }^{1}$ Festus Dogunro' ${ }^{1}$, Cosmas Onwude ${ }^{1}$, \\ Nneka Agashi', Ebuka Ezihe1', Clementina Anioke', Stephen Anokwu', Emelda Eloy', Peter Attah', \\ Francis Orizu', Sylvester Ewo ${ }^{1}$, Angela Okoronkwo ${ }^{1}$, Anumba Joseph ${ }^{1}$, ljeoma Ikeakor ${ }^{1}$, Sylvester Haruna ${ }^{2}$ \\ and Virgile Gnanguenon ${ }^{3^{*}}$
}

\begin{abstract}
Background: Progress made in the control of malaria vectors globally is largely due to the use of insecticides. However, success in the fight against malaria has slowed down or even stalled due to a host of factors including insecticide resistance. The greatest burden of the disease is felt in Africa, particularly Nigeria. Unfortunately, adequate information on insecticide resistance is lacking in many parts of the country, particularly the South-East Zone. Hence, this study aims to bridge the information gap in the Zone.

Methods: The study was conducted from April to December 2016. Anopheles gambiae (s.l.) larvae and pupae were collected from one community each, in the five states of the South-East Zone and reared to the adult stage. The adults were subjected to bioassays for insecticide resistance in accordance with the World Health Organization test procedures, across the four classes of insecticides used in public health. The mosquitoes were also subjected to molecular identification to the species level, and genotyped for West African knockdown resistance mutation (L1014F) and insensitive acetylcholinesterase-1 resistance mutation (G119S).

Results: The mosquitoes were susceptible (100\%) to bendiocarb but resistant to pirimiphos-methyl (39.6\%), deltamethrin (57\%) and dichlorodiphenyltrichloroethane (DDT) (13\%). Molecular analysis revealed that only An. gambiae (sensu stricto) was found in all the states except for Ebonyi, where only Anopheles coluzzii was present. High frequencies (0.6-0.9) of the L1014F mutation were found across the zone. The L1014F mutation was significantly higher in An. gambiae (s.s.) than in $A n$. coluzzii $(P<0.0001)$. A relatively low frequency $(0.2)$ of the G119S mutation was found in $A n$. coluzzii, and only in Ebonyi State.
\end{abstract}

Conclusion: The results show that mosquitoes collected from the South-East Zone of Nigeria were resistant to all insecticides used, except for bendiocarb. The presence of $\mathrm{L} 1014 \mathrm{~F}$ and $\mathrm{G} 119 \mathrm{~S}$ resistance mutations reported in this study calls for urgent attention to stop the growing threat of insecticide resistance in the country.

Keywords: Insecticide resistance, Anopheles, Knockdown resistance, Acetylcholinesterase-1 resistance, South-East Nigeria

*Correspondence: amerusangel@yahoo.fr

${ }^{3}$ Centre de Recherche Entomologique de Cotonou, Cotonou, Benin

Full list of author information is available at the end of the article

(c) The Author(s) 2020. This article is licensed under a Creative Commons Attribution 4.0 International License, which permits use, sharing, adaptation, distribution and reproduction in any medium or format, as long as you give appropriate credit to the original author(s) and the source, provide a link to the Creative Commons licence, and indicate if changes were made. The images or other third party material in this article are included in the article's Creative Commons licence, unless indicated otherwise in a credit line to the material. If material is not included in the article's Creative Commons licence and your intended use is not permitted by statutory regulation or exceeds the permitted use, you will need to obtain permission directly from the copyright holder. To view a copy of this licence, visit http://creativeco mmons.org/licenses/by/4.0/. The Creative Commons Public Domain Dedication waiver (http://creativecommons.org/publicdomain/ zero/1.0/) applies to the data made available in this article, unless otherwise stated in a credit line to the data. 


\section{Background}

The fight against malaria yielded significant results between the year 2000 and 2015. Within this period, there was a global decline of $18 \%$ and $48 \%$ in malaria cases and deaths, respectively [1]. Beyond 2015, progress seems to have slowed and is almost stalled. According to the World Malaria Report 2018, there were 219 million cases and 435,000 deaths caused by the disease in 2017 . In 2017, Africa accounted for an estimated $92 \%$ of global malaria cases and 93\% of deaths [2]. The ten highest burden African countries recorded 3.5 million more cases in 2017 than they did in the year 2016 [2].

Nigeria alone accounted for about $25 \%$ and $19 \%$ of global totals of estimated malaria cases and deaths, respectively [2]. Of the 3.5 million more cases recorded by the highest burden countries, Nigeria accounted for 1.3 million (37\%) cases. According to the WHO, there is an urgent need for accelerated reduction in incidence of the disease in high-burden countries, if global progress is to improve. Unfortunately, malaria incidence seems to be on the rise in Nigeria [2].

Vector control is a major pillar of malaria control. However, insecticide-treated nets (ITNs) and indoor residual spraying (IRS) are the mainstay of vector control, globally [3]. Until the year 2016, control of the malaria vectors hinges on the four classes of insecticides (pyrethroids, carbamates, organophosphates and organochlorines) approved by the World Health Organization Pesticide Evaluation Scheme (WHOPES). A new fifth class of insecticide (neonicotinoids) is now being used and tested in many countries and represent a new opportunity for vector control. The global decline in malaria cases and deaths observed between 2000 and 2015 is hugely attributed to use of insecticides in IRS and LLINs. Between 2013 and 2015, 93 million ITNs were distributed in Nigeria and around $46 \%$ of people were sleeping under ITNs (protected) in 2015 [4]. The IRS coverage was very low with only $2.5 \%$ all the states in the six geopolitical zones of Nigeria covered [5]. This information suggested an important gap of vector control tools that still need to be deployed based on local evidence on malaria vectors susceptibility to the insecticides.

The huge gains made in the fight against malaria, using these tools, is threatened by widespread insecticide resistance [1]. Between 2010 and 2017, the World Malaria Report 2018 shows that there was resistance to at least one insecticide in one malaria vector from at least one location in 68 of the 80 malaria endemic countries that reported standard monitoring data. According to the report, $22(32 \%)$ of the countries detected resistance to all four classes, $16(24 \%)$ to three classes, $19(28 \%)$ to two classes and $11(16 \%)$ to one class. Resistance to these four insecticide classes was detected in vectors present in all WHO regions except for the WHO European Region, although the extent of monitoring and prevalence of confirmed resistance to each insecticide class differed between regions. Incidentally, there is also widespread vector resistance to various classes of insecticides in Nigeria [6-11].

A relatively small amount of information is available on the vectors and their resistance status in southern Nigeria. The dearth of information on malaria vectors is worst in the southeast zone of Nigeria [12]. Some isolated studies in the South-East Zone have shown that the major malaria vector, Anopheles gambiae (s.l.), is resistant to three (organochlorine, pyrethroid and organophosphate) of the four classes of insecticides $[9,13]$. However, these studies did not consider the various mechanisms driving insecticide resistance in the various locations.

This study sought to investigate the resistance status of malaria vectors and their underlying mechanisms, in the South-East Zone of Nigeria.

\section{Methods \\ Study area}

The South-East geopolitical zone is made up of 5 states (Abia, Anambra, Ebonyi, Enugu and Imo). It lies mainly in the forest belt of the country. There are two distinct seasons in this zone, the rainy season (April-November) and the dry season (December-March). The mean annual rainfall range is $3000-4000 \mathrm{~mm}$, while the mean annual temperature range is $30.0-36.0^{\circ} \mathrm{C}$ [12].

The 2006 national census estimates population of the zone to be $16,381,729$. Population of the zone at present is estimated to be about 22,279,151 (assuming a national growth rate of 3\%). With a total surface area of 29,095 $\mathrm{km}^{2}$, the South-East Zone has an estimated population density of 766 persons $/ \mathrm{km}^{2}$.

The study was carried out in Isuochi, Umunneochi Local Government Area (LGA), Abia State $\left(6.0057200^{\circ}\right.$ $\left.\mathrm{N}, 7.4017600^{\circ} \mathrm{E}\right)$; Ukpor, Nnewi South LGA, Anambra State $\left(5.9076300^{\circ} \mathrm{N}, 6.9343600^{\circ} \mathrm{E}\right)$; Afikpo, Afikpo North LGA, Ebonyi State $\left(5.8895^{\circ} \mathrm{N}, 7.9538^{\circ} \mathrm{E}\right)$; Amaechi-Idodo, Nkanu East LGA, Enugu State $\left(6.461253^{\circ} \mathrm{N}\right.$; $7.725586^{\circ} \mathrm{E}$ ); and Ndianichie Uno, Ideato North LGA, Imo State $\left(5.8897^{\circ} \mathrm{N}, 7.1629^{\circ} \mathrm{E}\right)$ (Fig. 1).

\section{Larval survey}

The larvae collections were conducted from April (rainy season) to December (dry season) 2016. To ensure that populations of all possible vectors breeding in the study area were collected, extensive larval sampling was embarked upon. Puddles, rivers, streams, rice fields and other farms, containers, excavations, tire tracks, hoof prints and crab holes were sampled among others. 




South East States Showing Study Sites

Fig. 1 Southeast states showing study sites

Dippers, ladles, siphons and pipettes were used to ensure that each site in the study area was combed in the course of prospecting for larvae and pupae.

All larvae and pupae collected were placed in labeled containers according to the site of collection and transported to the insectary at the National Arbovirus and Vectors Research Centre (NAVRC), Enugu, Nigeria. They were then reared to adulthood, for susceptibility tests. The larvae were fed with fish feed (Tropical Flakes, Samyu Pets Corp, Shulin City, Taiwan) in $500 \mathrm{ml}$ larval bowls. On emergence, the adult mosquitoes were fed with a $10 \%$ sugar solution in cotton wool. Throughout this period, the relative humidity and temperature were maintained at $80 \pm 10 \%$ and $25 \pm 2{ }^{\circ} \mathrm{C}$, respectively.

\section{WHO susceptibility test}

To determine the resistance status of the malaria vectors, non-blood-fed An. gambiae (s.l.) females that were 3 to 5 days post-emergence were used for susceptibility tests according to the WHO test procedures [14]. Adults of An. gambiae (s.l.) from all sites in the study area were tested against $0.25 \%$ pirimiphos-methyl (organophosphates), 0.1\% bendiocarb (carbamates), 0.05\% deltamethrin (pyrethroids) and 4\% DDT (organochlorines). A total of 100 mosquitoes were exposed for $60 \mathrm{~min}$ to each insecticide (using four replicates) and 50 mosquitoes for the controls (using two replicates). The test conditions were maintained at a temperature of $26 \pm 3{ }^{\circ} \mathrm{C}$ and a relative humidity of $74 \pm 4 \%$. Mosquitoes that survived were preserved for target site resistance (kdr-w and Ace- $1^{\mathrm{R}}$ ) assays, using silica gel in Eppendorf tubes.

\section{Morphological identification of vector species}

All adult mosquitoes subjected to the test were identified at the NAVRC laboratory using the keys of Gillies \& DeMeillon [15], Gillet [16] and Gillies \& Coetzee [17].

\section{Molecular identification of Anopheles species DNA extraction}

Around 30 An. gambiae (s.l.) were selected randomly by site from live and dead mosquitoes ( 15 from pirimiphos-methyl tests and 15 from deltamethrin tests) and subjected to polymerase chain reaction (PCR) amplification for species identification and resistance mechanism detection. Genomic DNA from whole female mosquitoes was extracted according to the standard procedures of Collins et al. [18]. Extracted DNA was resuspended in 50 $\mu \mathrm{PCR}$ grade water. 


\section{PCR for molecular species identification}

PCR tests were performed with universal and speciesspecific primers for the An. gambiae complex. The SINE 200 PCR protocol [19] was used to simultaneously identify members of the An. gambiae complex and their former molecular forms.

\section{PCR for resistance mechanisms detection}

PCR analyses were performed at the Center of Entomological Research of Cotonou, the Republic of Benin. The PCR-restriction fragment length polymorphism diagnostic test was performed to identify the presence of the L1014F mutation $(k d r)$ using the method described by MartinezTorres et al. [20]. The following primers were used: Agd1 (5'-ATA GAT TCC CCG ACC ATG-3'), Agd2 (5'-AGA CAA GGA TGA TGA ACC-3'), Agd3 (5'-AAT TTG CAT TAC TTA CGA CA-3') and Agd4 (5'-CTG TAG TGA TAG GAA ATT TA-3'). The PCR was performed in a $25 \mu \mathrm{l}$ mixture including $17.1 \mu \mathrm{l}$ distilled water, $2.5 \mu \mathrm{l} 10 \times$ PCR buffer (TEKNOVA, California, USA), $0.3 \mu \mathrm{l} \mathrm{MgCl}_{2}$, $1 \mu \mathrm{l}$ of each primer, $1 \mu \mathrm{l}$ of dNTP and $0.125 \mu \mathrm{l}$ of kappa Taq DNA polymerase (Kapa Biosystems, Cape Town, South Africa). The cycling conditions were initially set as $95^{\circ} \mathrm{C}$ denaturation for $3 \mathrm{~min}$, followed by 10 cycles of $1 \mathrm{~min}$ at $94{ }^{\circ} \mathrm{C}, 30 \mathrm{~s}$ at $54{ }^{\circ} \mathrm{C}$ and $30 \mathrm{~s}$ at $72{ }^{\circ} \mathrm{C}$. This was followed by 30 cycles of $1 \mathrm{~min}$ at $94{ }^{\circ} \mathrm{C}, 30 \mathrm{~s}$ at $47^{\circ} \mathrm{C}$ and $30 \mathrm{~s}$ at $72{ }^{\circ} \mathrm{C}$, with a final extension step at $72^{\circ} \mathrm{C}$ for $10 \mathrm{~min}$. The PCR products were verified on a $2 \%$ agarose gel and stained with ethidium bromide for visualization using a Syngene bio-imaging system (Syngene, Cambridge, UK). G119S mutation (Ace-1R) was detected using the method described by Weill et al. [21]. The primers MOUSTDIR1 (25 pmol/ $\mu \mathrm{l})\left(5^{\prime}\right.$-CCG GGN GCS ACY ATG TGG AA-3'); and MOUSTREV1 $(25 \mathrm{pmol} / \mu \mathrm{l})\left(5^{\prime}\right.$-ACG ATM ACG TTC TCY TCC GA-3') were used. The G119S mutation PCR was performed in a $25 \mu \mathrm{l}$ mixture including $16.35 \mu \mathrm{l}$ sterile water, $5.0 \mu \mathrm{l}$ of $5 \times$ GoTaq PCR Buffer (Promega, Wisconsin, USA), $1.0 \mu \mathrm{l}$ dNTP, $1.25 \mu \mathrm{l}$ of each primer and $0.15 \mu \mathrm{l}$ Taq DNA. The cycling conditions were $93{ }^{\circ} \mathrm{C} / 5 \mathrm{~min} \times 1$ cycle, $\left(93{ }^{\circ} \mathrm{C} / 1 \mathrm{~min}-0-53{ }^{\circ} \mathrm{C} / 1 \mathrm{~min}-0-72{ }^{\circ} \mathrm{C} / 1.5 \mathrm{~min}\right) \times 35$ cycles, $72{ }^{\circ} \mathrm{C} / 10 \mathrm{~min} \times 1 \mathrm{cycle}$, and $4{ }^{\circ} \mathrm{C}$ of holding temperature. A total of $15 \mu \mathrm{l}$ of the PCR product was digested with $1 \mu \mathrm{l}$ Alu $\mathrm{I}$ restriction enzyme, $2 \mu \mathrm{l}$ of $\mathrm{H}_{2} 0$, and $2 \mu \mathrm{l}$ buffer. The incubation period was $37^{\circ} \mathrm{C}$ for $8-24 \mathrm{~h}$. Following incubation, $5 \mu \mathrm{l}$ of the digest was analysed on $2 \%$ agarose gel and stained in ethidium bromide.

\section{Data analysis and interpretation}

The resistance status of mosquito samples was determined according to the WHO protocol for insecticide resistance monitoring [14] as follows: mortality rate $>98 \%$, the population was considered fully susceptible; mortality rates of 90-98\%, resistance suspected in the population; mortality rates $<90 \%$, the population was considered resistant to the tested insecticides

Abbott's formula should be used to correct the observed mortality when the mortality in the control is between 5-20\% [22]. However, the mortality rates in all controls were less than 5\% during the tests and the use of Abbott's formula was not required to correct mortality rates.

The Fisher's exact test was used to compare mortality rates among the mosquito populations using GENEPOP software [23]. To assess variability of the allelic frequencies of the $k d r(\mathrm{~L} 1014 \mathrm{~F})$ mutation and Ace- $1^{\mathrm{R}}$ (G119S) across populations, the genotypic differentiation test was performed [24].

\section{Results}

Susceptibility of Anopheles gambiae (s.l.)

from the South-East Zone to deltamethrin (pyrethroid) and DDT insecticides

The average mortality of An. gambiae (s.l.) populations tested with DDT was 13\% (95\% CI: 6.55-19.45\%). Observed mortality in the states was as follows: Enugu State: 6\% (95\% CI: 2.23-12.60\%); Abia State: 9\% (95\% CI: 4.19-16.39\%) (Fig. 2); Anambra and Imo States: 16\% (95\% CI: 9.43-24.67\%). The highest mortality with DDT was observed in Ebonyi State (18\%; 95\% CI: 11.03-26.94\%) (Figs. 2, 3).

For pyrethroid and deltamethrin, the average mortality observed was 57\% (95\% CI: 30.95-83.05). This mortality varied from one state to another. The observed mortality with deltamethrin was $26 \%$ (95\% CI: 17.74-35.73\%) in Abia State (Fig. 2), 52\% (95\% CI: 41.77-62.09\%) in Anambra State, 60\% (95\% CI: 49.72-69.67\%) in Imo State and 63\% (95\% CI: 52.76-72.44\%) in Ebonyi State. The highest

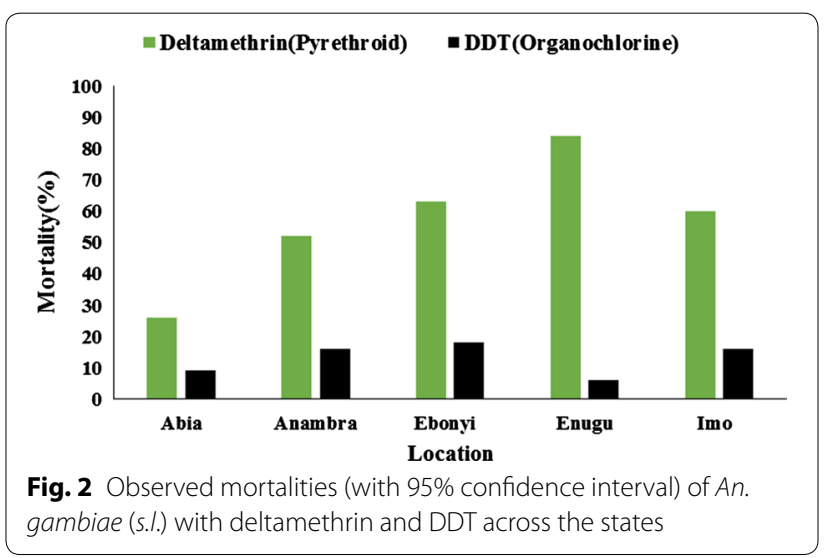






Fig. 3 Distribution of insecticide resistance in South-East Nigeria

mortality with deltamethrin was $83 \%$ (95\% CI: $75.32-$ 90.56\%) and was observed in Enugu State (Figs. 2, 3).

\section{Susceptibility of Anopheles gambiae (s.I.)}

from the South-East Zone to bendiocarb (carbamate) and pirimiphos-methyl (organophosphate) insecticides The average mortality observed with bendioacarb was $100 \%$. A mortality rate of $100 \%$ was observed in all states assessed (Figs. 3, 4).
With the organophosphate pirimiphos-methyl, the average mortality observed across all states was 39.6\% (95\% CI: 6.4-72.8\%). At a state level, the observed mortalities were 8\% (95\% CI: 3.51-15.15\%) in Abia State, $14 \%$ (95\% CI: 07.87-22.37\%) in Ebonyi State, 52\% (95\% CI: 41.77-62.09\%) in Enugu State and 57\% (95\% CI: 46.71$66.86 \%$ ) in Imo State (Fig. 4). The highest mortality with pirimiphos-methyl was observed in Anambra State with a mortality of 67\% (95\% CI: 56.88-76.08\%) (Figs. 3, 4). 


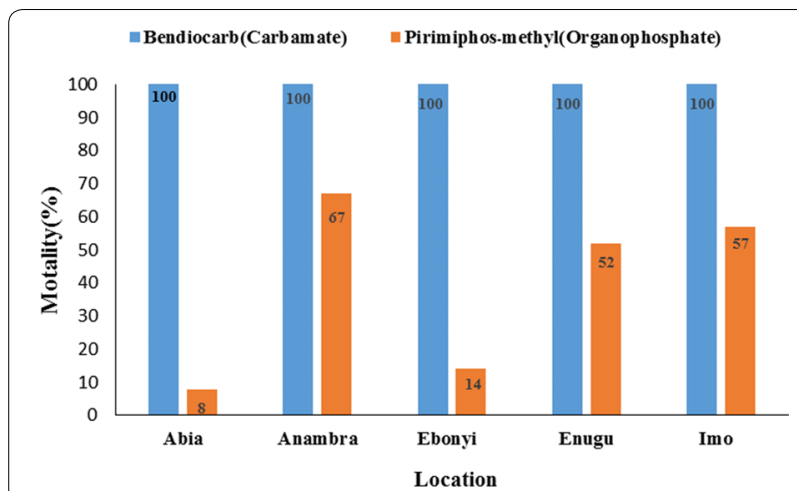

Fig. 4 Observed mortalities (with 95\% confidence interval) of An. gambiae (s.l.) with pirimiphos-methyl and bendiocarb across the states

\section{Distribution of sibling species of Anopheles gambiae (s.l.) across the states}

All An. gambiae (s.l.) tested from Abia, Anambra, Ebonyi and Imo States were identified to be An. gambiae (s.s.) (Table 1). On the contrary, the mosquitoes tested from Ebonyi State were all Anopheles coluzzii (Table 1). Samples from Enugu were not subjected to testing in this assay.

\section{Distribution of L1014F and G119S mutations in kdr genes across the states}

Target site resistance was assayed in the mosquitoes collected from four of the five South-East states. The GII9S mutation was detected at low frequencies (0.2) in mosquitoes collected from Ebonyi State only (Table 2). This mutation was detected in its heterozygote state in $A n$. coluzzii which seemed to be breeding in allopatry in the

Table 1 Distribution of An. gambiae (s.s.) and An. coluzzii across the states

\begin{tabular}{lllll}
\hline Species & Abia & Anambra & Ebonyi & Imo \\
\hline An. gambiae (s.s.) (\%) & 100 & 100 & 0 & 100 \\
An. coluzzii (\%) & 0 & 0 & 100 & 0 \\
Total & 30 & 30 & 30 & 30 \\
\hline
\end{tabular}

Table 2 Frequency of Ace-1 resistance across the states

\begin{tabular}{llllll}
\hline Location & $n$ & RR & RS & SS & $F\left(\right.$ Ace-1 $\left.{ }^{R}\right)$ \\
\hline Afikpo, Ebonyi State & 30 & 0 & 6 & 24 & 0.2 \\
Isuochi, Abia State & 30 & 0 & 0 & 30 & 0 \\
Ndianiche-Uno, Imo State & 30 & 0 & 0 & 30 & 0 \\
Ukpo, Anambra State & 30 & 0 & 0 & 30 & 0 \\
Total & 120 & 0 & 6 & 114 & 0.025 \\
\hline
\end{tabular}

Abbreviations: $\mathrm{n}$, number tested; SS, homozygous susceptible; RS, hybrid resistant and susceptible; $R R$, homozygous resistant; $F$, frequency state. On the other hand, mutations in the $k d r$ gene were detected in Anopheles mosquitoes collected from all states tested (Table 3). The resistance frequencies were high in both An. coluzzii which recorded a frequency of 0.6, and An. gambiae (s.s.) which had an average frequency of 0.85 across all states from which they were collected (Table 4). The frequency of $k d r$ resistance in $A n$. gambiae (s.s.) was significantly higher than that of $A n$. coluzzii $(P<0.001)$ (Table 4$)$.

\section{Discussion}

The present study is in part an update on the 2014 and 2015 insecticide resistance monitoring of the An. gambiae (s.l.) in Enugu State and an expansion to other states in the Zone. The expansion to other states is to bridge the enormous information gap on malaria vectors and their resistance status in the study area. The results revealed that An. gambiae (s.l.) populations were resistant to organophosphates, pyrethroids and DDT. They were only susceptible to the carbamates, particularly, bendiocarb. High knockdown resistance frequencies were observed in the mosquito populations of the study area. The acetylcholinesterase-1 resistance frequencies were low among the mosquito populations tested.

In 2014 and 2015, malaria vector populations showed the greatest resistance against DDT and then pyrethroids $[9,25]$. This may be due to excessive use of DDT in the past, which may also have conferred resistance on the pyrethroids through cross-resistance. Additionally, LLINs have been widely distributed in the South-East Zone for about a decade. The fact that the pyrethroids are the only class of insecticide used in LLINs is likely to have exacerbated the situation. Across the five states, deltamethrin performed better than the organochlorine and organophosphate used in this study. This may not be reflective of the overall performance of the different insecticides in the pyrethroid class. Deltamethrin being a type II pyrethroid contains an alpha-cyano group allowing it to exert a better killing effect on insects [26]. However, results of this study corroborate with the recent finding in Amansea, Anambra State, by Nwankwo et al. [10], where malaria vectors were only susceptible to the carbamate, bendiocarb.

Widespread resistance of An. gambiae (s.l.) to DDT and pyrethroids has been reported by various studies in Nigeria $[6-8,11]$ and other parts of Africa [27-30]. This may be largely due to cross-resistance, use of agricultural insecticides and/or use of pyrethroids in LLINs and IRS. On the contrary, resistance to pirimiphos-methyl (organophosphate) is not as widespread as those of DDT and the pyrethroids. Anopheles gambiae (s.l.) susceptibility to the insecticide has been reported in some parts of South-West Nigeria $[9,10]$. The vectors were found to 
Table 3 Frequency of knock-down resistance mutation ( $k d r)$ across the states

\begin{tabular}{|c|c|c|c|c|c|c|c|c|}
\hline Location & $n$ & $\mathrm{RR}$ & RS & SS & $\mathrm{F}(k d r)$ & Odds ratio & $95 \% \mathrm{Cl}$ & $P$-value \\
\hline Afikpo, Ebonyi State & 30 & 12 & 12 & 6 & 0.60 & - & - & - \\
\hline Isuochi, Abia State & 30 & 24 & 3 & 3 & 0.85 & 3.70 & $1.57-9.39$ & 0.002 \\
\hline Ndianiche-Uno, Imo State & 30 & 24 & 6 & 0 & 0.90 & 5.81 & $2.26-17.26$ & $<0.001$ \\
\hline Ukpo, Anambra State & 30 & 18 & 12 & 0 & 0.80 & 2.63 & $1.17-6.16$ & 0.018 \\
\hline Total & 120 & 78 & 33 & 9 & 0.79 & & & \\
\hline
\end{tabular}

Abbreviations: SS, homozygous susceptible; RS, hybrid resistant and susceptible; RR, homozygous resistant; $\mathrm{F}$, frequency; $\mathrm{Cl}$, confidence interval

Table 4 Frequency knock-down resistance mutation ( $k d r)$ across mosquito species

\begin{tabular}{|c|c|c|c|c|c|c|c|c|}
\hline Species & $n$ & $\mathrm{RR}$ & RS & SS & $F(k d r)$ & Odds ratio & $95 \% \mathrm{Cl}$ & $P$-value \\
\hline An. gambiae (s.s.) & 90 & 66 & 21 & 3 & 0.85 & 0.27 & $0.14-0.52$ & $<0.001$ \\
\hline An. coluzzii & 30 & 12 & 12 & 6 & 0.60 & & & \\
\hline Total & 120 & 78 & 33 & 9 & 0.79 & & & \\
\hline
\end{tabular}

Abbreviations: $\mathrm{SS}$, homozygous susceptible; $\mathrm{RS}$, hybrid resistant and susceptible; $\mathrm{RR}$, homozygous resistant: $\mathrm{F}$, frequency; $\mathrm{Cl}$, confidence interval

be susceptible to both the organophosphates and carbamates in Lagos and Oyo States. However, resistance to pirimiphos-methyl has been recorded in several other geopolitical zones of Nigeria [9]. The high resistance observed with pirimiphos-methyl could be due to the fact that this insecticide was among the pesticides widely used in the previous years for crop control in agriculture as reported by Odeyemi et al. [31] and the West Africa Productivity Programme [32] and could have exerted a high selection pressure on mosquito larvae.

Target site resistance was the only mechanism of resistance analysed in this study. Nevertheless, target site resistance is a major mechanism driving vector insecticide resistance in Nigeria [33]. The West African knockdown resistance (L1014F) was found in high frequencies (between 0.6-0.9) across the states. The homozygous resistance state (RR) dominated the allelic frequency in all the states. Anopheles gambiae (s.s.) and An. coluzzii showed similar L1014F frequencies. This agrees with the findings of Gnanguenon et al. [29] and Okorie et al. [9], where the L1014F mutation was found in both populations. However, it contrasts a report by AIRS Nigeria [11] where populations of An. coluzzii collected from the study were all negative for the L1014F mutation.

In contrast to L1014F, acetylcholinesterase resistance (G119S mutation) was observed at a low frequency (0.2). It was only found in its heterozygous genotype (RS) state in an An. coluzzii population collected from Ebonyi State. The dominant An. gambiae (s.s.) tested from all the states were negative for G119S mutation. This may be the first time the insensitive acetylcholinesterase- 1 mutation is detected in malaria vectors in Nigeria, as there has been no record of it between 2010 and 2016 [34] in the country. Our finding is in contrast with a study by Gnanguenon et al. [29] in Benin, where all An. coluzzii were negative to the insensitive acetylcholinesterase-1 gene. However, despite the very low frequency of the G119S mutation, organophosphate resistance was observed in all the states. This suggests that other resistance mechanisms such as metabolic resistance which confers crossresistance to organophosphates and carbamates could be involved in the vector populations. This corroborates the studies by Djouaka et al. [34] and Awolola et al. [8] reporting multiple resistance mechanisms in malaria vectors in various locations of Nigeria. If the frequency of the G119S mutation is low (as identified in the present study) and esterase activity is high, it is possible for the vectors to be susceptible to the carbamates and resistant to the organophosphates [35]. This could occur because esterase activity exerts relatively little effect on the carbamates but a huge effect on the organophosphates. The presence of the G119S mutation needs to be significant alongside some other metabolic resistance for a possible expression of phenotypic resistance to carbamates. Hence, our findings suggest that esterase activity in the Anopheles populations tested may be high.

Our findings suggest that the vectors breed in allopatry in all the states tested. However, more studies should be carried out in all states, to better understand the spread of An. gambiae (s.s.) and An. coluzzii. Meanwhile, to the best of our knowledge, this is the first-time allopatric breeding for the two sibling species has been reported in such a large scale coordinated study in Nigeria. This is in contrast with the findings of Awolola et al. [7, 27], 
Okorie et al. [9] and Djouaka et al. [34] recording sympatric breeding of the two members of the An. gambiae complex.

Despite of the significant findings observed in the study, it does have its limitations. The intensity of the observed resistance was not assessed. The presence of L1014S and N1575Y mutations which are important target site mutations in An. gambiae (s.l.) was not documented. The metabolic resistance and transcriptional analyses for metabolic resistance mechanisms were not carried out in the study and constituted an important limitation. The inclusions of these resistance mechanisms would have provided a clear profile of insecticide resistance in southeast Nigeria. However, a recent study conducted by Ibrahim et al. [36] demonstrated that metabolic resistance (CYP450) is present in the malaria vector population with a synergist significant recovery observed after exposure of wild An. gambiae (s.l.) from the SaheloSudanian region of northern Nigeria to synergist plus deltamethrin. Biochemical analyses in another study from surveillance sites of Nigeria [37] demonstrated a significant increase in the levels of P450 enzymes in a resistant An. gambiae population from Lagos, Ogun and Niger states. The same study also showed the presence of glutathione S-transferase (GST) mechanism in Lagos and Ogun revealing an increasing presence of metabolic resistance $(\mathrm{P} 450+\mathrm{GST})$ in malaria vectors from Nigeria. These findings are also confirmed by Fagbohoun et al. [38] who demonstrated that cytochrome P450 monooxygenase resistance was highly involved in the resistance of An. gambiae to DDT and pyrethroids.

The presence of the L1014S-kdr mutation has been recently reported in a single $A n$. arabiensis from the Sudan savannah of northern Nigeria by Ibrahim et al. [39]. However, Habibu et al. [40] have reported a higher frequency of L1014S-kdr mutation in An. coluzzii and $A n$. arabiensis mosquitoes than previously reported by Ibrahim et al. [39]. These findings suggest an increasing L1014S-kdr mutation rate in Nigeria. As yet, the N1575Y mutation has not been reported in Nigeria but has been reported in the West African regions of Côte d'Ivoire and Burkina Faso and could therefore potentially spread to Nigeria $[41,42]$. In the present study, only a small number of samples $(n=30)$ were used for PCR due to limited funding to perform the analysis and this represented an important limitation. A more accurate estimation of resistance mechanisms could have been obtained using a larger sample size.

Monitoring insecticide resistance is an important strategy against malaria vectors and the resistance management strategies depends on the evidences of local vector resistance to insecticides. This data will be beneficial to the National Malaria Control Programme, as the results will assist them with their choice of insecticide for use in southeast Nigeria. A pro-active strategy should be used to avoid vector resistance to bendiocarb. Alternative new insecticides such as neonicotinoids (clothianidin and a combination of clothianidin/deltamethrin) could be used in rotation or mosaic with bendiocarb as a local resistance management strategy.

\section{Conclusions}

The study demonstrated a widespread resistance to three of the four classes of insecticides used in public health in the South-East Zone of Nigeria. This could have huge implications in the control of malaria and its vectors in the Zone, as most of the vector control interventions rely heavily on insecticides from these classes. There is an urgent need for implementation of insecticide resistance management strategies in the Zone to assess the spread of resistance. Moreover, the detection of G119S resistance supports the urgent need of an insecticide resistance management plan. The spread of G119S resistance will expand malaria vector resistance to the remaining class of insecticide (carbamate). Hence, there is a need for continuous and expanded insecticide resistance monitoring in the Zone to obtain a broader and clearer idea of the situation.

\section{Abbreviations}

LGA: Local Government Area; NAVRC: National Arbovirus and Vectors Research Centre; s.l.: sensu lato.

\section{Acknowledgements}

The Centre (NAVRC) is grateful to the Federal Government of Nigeria for the financial support to carry out this study. We also appreciate the support of various State Governments, Local Government Councils, and communities where parts of this work were done. Without your support, this study would not have been successful.

\section{Authors' contributions}

$\mathrm{OC}, \mathrm{SH}, \mathrm{FD}, \mathrm{UN}, \mathrm{CO}$ and NA designed the study. EN, FD, UN, CO, NA, EE, CA, $\mathrm{SA}, \mathrm{EE}, \mathrm{PA}, \mathrm{FO}, \mathrm{SE}, \mathrm{AO}, \mathrm{AJ}$ and II carried out the experiments. UN, CO and VG analyzed the data. AJ prepared the map. OC drafted the manuscript. OC, UN, VG and CO critically revised the manuscript. All authors read and approved the final manuscript.

\section{Funding}

The research was funded by the Federal Government of Nigeria.

Availability of data and materials

All data generated or analyzed during this study are included in this published article.

Ethics approval and consent to participate

Not applicable.

Consent for publication

Not applicable.

Competing interests

The authors declare that they have no competing interests. 


\author{
Author details \\ ${ }^{1}$ National Arbovirus and Vectors Research Centre (NAVRC), Enugu, Nigeria. \\ ${ }^{2}$ Department of Biological Sciences, Kogi State University, Anyigba, Nigeria. \\ ${ }^{3}$ Centre de Recherche Entomologique de Cotonou, Cotonou, Benin.
}

Received: 18 November 2019 Accepted: 17 March 2020

Published online: 24 March 2020

\section{References}

1. WHO. World Malaria Report 2015. Geneva: World Health Organization; 2015. p. 11-2. https://www.who.int/malaria/publications/world-malar ia-report-2015/report/en/. Accessed 11 Mar 2020.

2. WHO. World Malaria Report 2018. Geneva: World Health Organization; 2018. p. 32-59. https://www.who.int/malaria/publications/world-malar ia-report-2018/en/. Accessed 11 Mar 2020.

3. WHO. World Malaria Report 2017. Geneva: World Health Organization; 2017. p. 31-40. https://www.who.int/malaria/publications/world-malar ia-report-2017/en/. Accessed 11 Mar 2020.

4. WHO. World Malaria Report 2016. Geneva: World Health Organization; 2016. p. 13-71. https://www.who.int/malaria/publications/world-malar ia-report-2016/report/en/. Accessed 11 Mar 2020.

5. Ezenwa NL, Inuwa J, Adeyinka A, Henry K, Alain K, Narjis K. A verbal/ social autopsy study to improve estimates of the causes and determinants of neonatal and child mortality in Nigeria (2014) Healthy Newborn Network. 2016. https://www.healthynewbornnetwork.org/hnn-content/uploads/ Nigeria_2014-VASA-Study_final_report.pdf. Accessed 11 Mar 2020.

6. Awolola TS, Brooke BD, Hunt RH, Coetze M. Resistance of the malaria vector Anopheles gambiae s.s. to pyrethroid insecticides, in south-western Nigeria. Ann Trop Med Parasitol. 2002;96:849-52.

7. Awolola TS, Oduola AO, Oyewole IO, Obansa JB, Amajoh CN, Koekemoer $\mathrm{LL}$, et al. Dynamics of knockdown pyrethroid insecticide resistance alleles in a field population of Anopheles gambiae s.s. in southwestern Nigeria. J Vector Borne Dis. 2007:44:181-8.

8. Awolola TS, Oduola OA, Strode C, Koekemoer LL, Brooke B, Ranson H. Evidence of multiple pyrethroid resistance mechanisms in the malaria vector Anopheles gambiae sensu stricto from Nigeria. Trans R Soc Trop Med Hyg. 2009;103:1139-45.

9. Okorie PN, Ademowo OG, Irving H, Kelly-Hope LA, Wondji CS. Insecticide susceptibility of Anopheles coluzzii and Anopheles gambiae mosquitoes in Ibadan, Southwest Nigeria. Med Vet Entomol. 2015;29:44-50.

10. Nwankwo EN, Okorie PN, Acha CT, Okonkwo OE, Nwangwu UC, Ezihe EK. Insecticide resistance in Anopheles gambiae s.I. mosquitoes in Awka, Anambra State, Southeast Nigeria. J Mosq Res. 2017;7:32-7.

11. AIRS Project. AIRS Nigeria final entomology report. Abuja: Abt Associates; 2015. p. 11-3.

12. Nigerian Meteorological Agency. Nigeria Climate Review 2012. http:// www.nimet.gov.ng. Accessed 11 Mar 2020.

13. Awolola T, Bitsindou P, Bagayoko M, Manga L. Malaria entomological profile for Nigeria. WHO/AFRO document. 2007. http://afrolib.afro.who. int/documents/2009/en/Malentomology_nigeria.pdf. Accessed 11 Mar 2020

14. WHO. Test procedures for insecticide resistance monitoring in malaria vector mosquitoes, 2nd ed. Geneva: World Health Organization; 2016. https://apps.who.int/iris/bitstream/handle/10665/250677/9789241511 575-eng.pdf?sequence=1. Accessed 11 Mar 2020.

15. Gillies MT, de Meillon B. The anophelinae of Africa South of the Sahara. Publ South African Inst Med Res. 1968;54:1-343.

16. Gillett JD. Common African mosquitoes and their medical importance. London: William Heinemann; 1972.

17. Gillies MT, Coetzee M. A supplement to the Anophelinae of Africa south of the Sahara (Afrotropical region). Johanesburg: The South African Institute for Medical Research; 1987.

18. Collins FH, Mendez MA, Rasmussen MO, Mehaffey PC, Besansky NJ, Finnerty $\mathrm{V}$. A ribosomal RNA gene probe differentiates member species of the Anopheles gambiae complex. Am J Trop Med Hyg. 1987;37:37-41.

19. Santolamazza F, Mancini E, Simard F, Qi Y, Tu Z, della Torre A. Insertion polymorphisms of SINE200 retrotransposons within speciation islands of Anopheles gambiae molecular forms. Malar J. 2008;7:163.
20. Martinez-Torres D, Chandre F, Williamson MS, Darriet F, Berge JB, Devonshire $\mathrm{AL}$, et al. Molecular characterization of pyrethroid knockdown resistance $(k d r)$ in the major malaria vector Anopheles gambiae s.s. Insect Mol Biol. 1998;7:179-84.

21. Weill M, Malcolm C, Chandre F, Mogensen K, Berthomieu A, Marquine M, et al. The unique mutation in ace-1 giving high insecticide resistance is easily detectable in mosquito vectors. Insect Mol Biol. 2004;13:1-7.

22. Abbott WS. A method of computing the effectiveness of an insecticide. J Economic Entomol. 1925:18:265-7.

23. Raymond M, Rousset F. GENEPOP (version 1.2): population genetics software for exact tests and ecumenicism. J Hered. 1995;86:248-9.

24. Goudet J, Raymond M, de Meeüs T, Rousset F. Testing differentiation in diploid populations. Genetics. 1996;144:1933-40.

25. AIRS Project N. Entomological summary report II. Abuja: Abt Associates; 2014. p. 58.

26. WHO. Guidelines for laboratory and field-testing of long-lasting insecticidal nets. Geneva: World Health Organization; 2013 p. 1-102. https:// www.who.int/whopes/resources/9789241505277/en/. Accessed 11 Mar 2020.

27. Akogbeto $M$, Yakoubou S. Resistance of malaria vectors to pyrethrins used for impregnating mosquito nets in Benin, West Africa. Bull Soc Pathol Exot. 1999;92:123-30.

28. Nkya TE, Akhouayri I, Poupardin R, Batengana B, Mosha F, Magesa S, et al. Insecticide resistance mechanisms associated with different environments in the malaria vector Anopheles gambiae: a case study in Tanzania. Malar J. 2014;13:28.

29. Gnanguenon V, Agossa FR, Badirou K, Govoetchan R, Anagonou R, OkeAgbo F, et al. Malaria vectors resistance to insecticides in Benin: current trends and mechanisms involved. Parasit Vectors. 2015:8:223.

30. IRAC. Prevention and management of insecticide resistance in vectors of public health importance. 2nd ed. Bruxelles: IRAC; 2011. https://www. irac-online.org/content/uploads/VM-Layout-v2.6_LR.pdf. Accessed 11 Mar 2020.

31. Odeyemi OO, Gbaye OA, Akeju O. Resistance of Callosobruchus maculatus (Fab.) to pirimiphos methyl in three zones in Nigeria. 9th International Working Conference on Stored Product Protection, 15-18 October 2006, São Paulo, Brazil; 2006.

32. West Africa Agricultural Productivity Programme. Report of a baseline study on status of use, registration and regulations of pesticides in Nigeria. https://www.slideshare.net/waapp-nigeria/final-version-of-basel ine-studies-on-pestticide-use-submiited-to-waapp2013a1. Accessed 11 Mar 2020.

33. Chouaïbou MS, Fodjo BK, Fokou G, Allassane OF, Koudou BG, David JP, et al. Influence of the agrochemicals used for rice and vegetable cultivation on insecticide resistance in malaria vectors in southern Côte d'Ivoire. Malar J. 2016;15:426.

34. Djouaka RF, Bakare AA, Coulibaly ON, Akogbeto MC, Ranson H, Hemingway J, et al. Expression of the cytochrome P450s, CYP6P3 and CYP6M2 are significantly elevated in multiple pyrethroid resistant populations of Anopheles gambiae s.s. from southern Benin and Nigeria. BMC Genomics. 2008;9:538.

35. WHO. Global report on insecticide resistance in malaria vectors: 2010-2016. Geneva: World Health Organization; 2018. https://apps.who. int/iris/handle/10665/272533. Accessed 11 Mar 2020.

36. Ibrahim SS, Mukhtar MM, Datti JA, Irving H, Kusimo MO, Tchapga W, et al. Temporal escalation of pyrethroid resistance in the major malaria vector Anopheles coluzzii from Sahelo-Sudanian Region of northern Nigeria. Sci Rep. 2019;9:7395.

37. Awolola TS, Adeogun A, Olakiigbe AK, Oyeniyi T, Olukosi YA, Okoh H, et al, Pyrethroids resistance intensity and resistance mechanisms in Anopheles gambiae from malaria vector surveillance sites in Nigeria. PLoS One. 2018;13:e0205230.

38. Fagbohun IK, Oyeniyi TA, Idowu TE, Otubanjo OA, Awolola ST. Cytochrome P450 mono-oxygenase and resistance phenotype in DDT and deltamethrin-resistant Anopheles gambiae (Diptera: Culicidae) and Culex quinquefasciatus in Kosofe, Lagos, Nigeria. J Med Entomol. 2019;56:817-21.

39. Ibrahim SS, Manu YA, Tukur Z, Irving $H$, Wondji CS. High frequency of $k d r$ $\mathrm{L} 1014 \mathrm{~F}$ is associated with pyrethroid resistance in Anopheles coluzzii in Sudan savannah of northern Nigeria. BMC Infect Dis. 2014;14:441. 
40. Habibu UA, Andrew JS, Hapca S, Mukhtar MD, Yusuf YD. Malaria vectors resistance to commonly used insecticides in the control of malaria in Bichi, northern Nigeria. BAJOPAS. 2017;10:1-6.

41. Edi AVC, N'Dri BP, Chouaibou M, Kouadio FB, Pignatelli P, Raso G, et al. First detection of N1575Y mutation in pyrethroid resistant Anopheles gambiae in southern Côte d'Ivoire. Wellcome Open Res. 2017;2:71.

42. Jones CM, Liyanapathirana M, Agossa FR, Weetman D, Ranson H, Donnelly MJ, et al. Footprints of positive selection associated with a mutation
(N1575Y) in the voltage-gated sodium channel of Anopheles gambiae. Proc Natl Acad Sci USA. 2012;109:6614-9.

\section{Publisher's Note}

Springer Nature remains neutral with regard to jurisdictional claims in published maps and institutional affiliations.
Ready to submit your research? Choose BMC and benefit from:

- fast, convenient online submission

- thorough peer review by experienced researchers in your field

- rapid publication on acceptance

- support for research data, including large and complex data types

- gold Open Access which fosters wider collaboration and increased citations

- maximum visibility for your research: over $100 \mathrm{M}$ website views per year

At BMC, research is always in progress.

Learn more biomedcentral.com/submissions 